https://doi.org/10.34080/os.v20.22635

\section{First proven record of within- year nest reuse by a pair of Bramblings Fringilla montifringilla}

\author{
Första bevisade fallet av \\ àteranvändning av ett bo samma år hos \\ bergfink Fringilla montifringilla
}

\section{VLADIMIR YU. ARKHIPOV}

It is known that those solitarily breeding passerines that build open nests rarely reuse old nests within a single breeding season (Hafstad et al. 2005). Indeed, there are many reports specifically of Bramblings building a new nest before a replacement clutch is laid (Cramp \& Perrins 1994). Nevertheless, in the severe conditions at high latitudes, the strategy of reusing an old nest within the same season might be adaptive. I present here the first proven record of within-year nest reuse by a colour-ringed Brambling pair during a study in Central Siberia.

\section{Methods, study area and data collection}

A breeding population of the Brambling was studied over four consecutive breeding seasons between 1994 and 1997. The study area is situated in the middle taiga subzone of Central Siberia (Russia) at the Yenisei River (Ecological field station "Mirnoye," $62^{\circ} 20^{\prime} \mathrm{N}, 89^{\circ} \mathrm{E}$ ) in pristine floodplain forest. These floodplain habitats hold an extremely dense and diverse breeding community in comparison with taiga zone habitats. A detailed description of the floodplain habitats of the area and their bird communities is given by Bourski (1995). The study was restricted to the 50 ha floodplain plot on the west bank of the Yenisei. The plot includes both willow-thicket (Salix sp.) and upper coniferous-deciduous forest habitats. To obtain detailed survey data, territorial birds on the plot were mist-netted and fitted with a unique combination of plastic colour rings. In the study area, the Brambling occurred at a high mean density of 68 breeding pairs per $\mathrm{km}^{2}$ (range: $53-78$ over four years). In total 42 nests were found and 55 adults from these nest were colour-ringed (Arkhipov 2005).

\section{Results and discussion}

The incident of nest reuse after depredation was observed in June and July 1995. The fresh, newly built Brambling nest was found on 12 June, with its owners, a pair of colour-ringed birds sounding alarm calls nearby. Both birds were caught approximately $100-150 \mathrm{~m}$ from the nest site; the male was caught on 4 July, the female one day later. The nest was situated in the crotch of a young willow-tree trunk about $3 \mathrm{~m}$ above the ground. After a clutch of two eggs had been laid on 14 June, the nest was depredated on a day between 14 and 17 June. When I checked on 17 June, I found it empty but intact. The parent birds were not observed. Just in case, the nest was visited on 23 June. Now an incubating female was noted on it. On June 29, I counted five warm eggs, on 4 July two eggs and three hatchlings, and on 5 July four hatchlings and one egg in the nest. The original pair of colour-ringed birds, which I had registered with the first clutch, fed the nestlings. Clearly, the same pair that had laid the first clutch successfully raised three nestlings from the replacement clutch in the same nest. The nestlings left the nest on 13 July. During our study, the incubation period for the Brambling from the last egg was 10-12 days, which means that in this case, the female may have begun to lay eggs on 18-20 June, some 1 to 5 days after the first nest had been predated. Thus, the total number of eggs laid by 


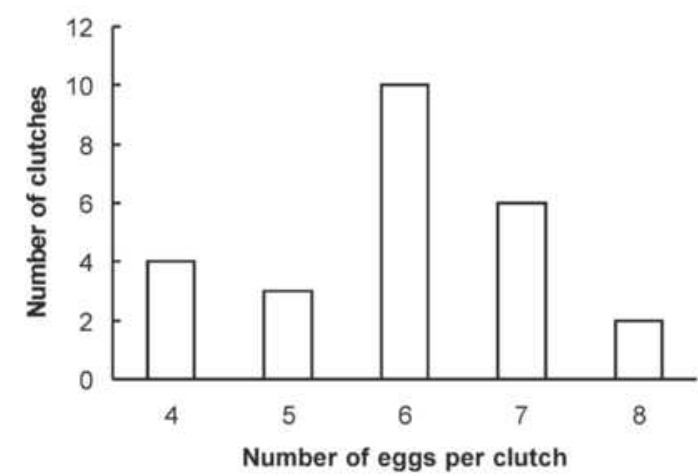

Figur 1. Distribution of size of clutches of Central Siberian Bramblings (our data).

Fördelningen av kullstorlekar hos bergfinkar i centrala Sibirien (egna data).

that female was from 7 to 10 , the maximum applying if the predation happened on about 17 July.

It is unlikely that the female would continue to lay to complete one clutch if the gap after depredation of the first part of the clutch was 4 to 5 days or greater. It is known that the Brambling can accommodate a gap in laying sequence of a single clutch of up to 5 days during periods of harsh weather (Hogstad 2000). However, the weather conditions during the period the nest was observed were extremely favorable. The total number of eggs laid in this case was 7, which is within the known limits of a single clutch (Figure 1). Consequently, we observed a true occurrence of within-year nest reuse where a replacement clutch was laid. The gap between laying the two lots of eggs was 5 days if the total number of eggs laid was 7, but only one day if the total was 10 (which would be greater than the known maximum size of a single clutch).

A similar case of Brambling nest reuse was reported from Tana $\left(70^{\circ} 16^{\prime} \mathrm{N}, 28^{\circ} 19^{\prime} \mathrm{E}\right)$, Norway Hafstad et al. (2005) for June 2003, where the gap between clutches was greater than a week. As there was no ringing of birds, this record lacks confirmation of the same bird laying both clutches. The authors report four other cases of potential nest reuse after it had been depredated in 2003, all four nests being depredated when they each contained 2 or 3 eggs, the birds were not colour-ringed as well. The gap between the depredation and the initiation of the second clutch in each case was only 1-3 days, the total number of eggs laid per female being between 5 and 7. The authors suggested that these incidents did not comprise clear cases of nest reuse, the evidence not ruling out that the obser- vations were just gaps in the laying sequence of a single clutch. However, all the incidents in this paper demonstrate in behavioural terms the ability of Bramblings to respond to clutch or part of clutch depredation and point to a possible capability of reusing a previously-built nest that had been predated, which response would demand separate egg-laying and incubation periods.

The fact of within-year nest reuse by Brambling is even more interesting to compare with behaviour of the closest relative, the Chaffinch Fringilla coelebs that lives further to the west and south. The Chaffinch is much more investigated, but no attempt to use old nests except for using them as material for new nest has ever been observed (Cramp \& Perrins 1994).

\section{Acknowledgements}

Warm thanks to Irina Rebrova, Vitaly Kontorschchikov and Alexandra Panaiotidi for their help in the field. My special gratitude goes to Oleg V. Bourski for his supervision and joint work at the Ecological field station "Mirnoye". I also thank Johan Reis for the valuable comments to the manuscript.

\section{References}

Arkhipov, V. Yu. 2005. Breeding biology of brambling (Fringilla montifringilla L.) in Taiga of the middle Yenisei. Byulleten Moskovskogo Obshchestva Ispytatelei Prirody. Otdel Biologicheskii 110 (2): 54-58. (In Russian, with English summary).

Bourski, O. V. 1995. Yenisei middle taiga breeding bird communities: overview and principal differences. Beiträge zur Naturkunde Niedersachsens 48: 133-156.

Cramp, S. and Perrins, C. M. Eds. 1994. Handbook of the birds of Europe, the Middle East and North Africa. The birds of the Western Palearctic. Vol. 8. Crows to finches. Oxford, Oxford University Press.

Hafstad, I., Stokke, B. G., Vikan, J. R., Rutila, J., Roskaft, E. and Moksnes, A. 2005. Within-year nest reuse in opennesting, solitary breeding passerines. Ornis Norvegica 28 (1): 58-61.

Hogstad, O. 2000: Bjørkefink - en karakterart for fjellbjørkeskogen. Vår Fuglefauna 23: 152-161.

\section{Sammanfattning}

Det är sällan som frihäckande fåglar lägger en ny kull i samma bo om boet plundras. Även hos bergfink finns många rapporter om att de bygger ett nytt bo för en omläggning, och detta är säkerligen det normala. Men under en flerårig studie av bergfink i centrala Sibirien observerades ett säkert fall där 
ett färgringmärkt par först fick en delvis lagd äggkull plundrad och senare registrerades mata ungar i samma bo. Detta är det första bevisade fallet, men en del tidigare indikationer på sådan återanvändning finns. Dessa är visserligen inte säkerställda, men kan indikera att vanan kan förekomma i viss frekvens hos just bergfinken. Hos bofinken, som är betydligt bättre studerad än bergfinken, har fenomenet aldrig rapporterats och torde därför inte förekomma. En tänkbar förklaring till att bergfink- en skulle återanvända samma bo efter plundring är att häckningssäsongen är kort på artens kärva latituder. Antalet dagar mellan förlust och omläggning kan förkortas om ett nytt bo inte behöver byggas, och därmed ökar chansen för den nya kullen.

Vladimir Yu. Arkhipov, Institute of Theoretical \& Experimental Biophysics, Russian Academy of Sciences, 142290 Pushchino, Moscow region, Russia. E-mail:v.arkhipov@rambler.ru 